\title{
COMPARATIVE STUDIES OF EDM MACHINING USING ALUMINIUM, BRASS AND COPPER
}

\author{
Gopi Kompelli \\ Vehicle Engineering \\ Kaunas University of Technology, Kaunas, Lithuania \\ Hari Prasanna Manimaran \\ Aeronautical Engineering \\ Kaunas University of Technology, Kaunas, Lithuania
}

\begin{abstract}
Electrical discharge machining (EDM) is also called as spark erosion and it is a non-traditional machining process which is based on the thermoelectric energy between the electrode and work specimen. In this procedure, the material removal is happened electro thermally by a progression of progressive discrete releases among anode and the workpiece [1]. In the EDM process, different electrode materials are used for comparative studied. EDM researchers are invented many ways to improve the sparking efficiency with including someone of a kind test ideas experimental concepts that depart from the EDM traditional sparking phenomenon [2]. The Material Removal Rate (MRR), Macro Graph (MG), Surface Roughness (SR), Signal to noise ratio (SN) is measured and recorded for detailed analysis. In the experimental process, different electrode materials are used like Aluminum, Brass, Copper kind of materials employed in the set of experiments and spo oil is used as the dielectric [3]. This experiment is to investigate the best material characteristic in terms of higher Material Removal Rate (MRR), low signal to noise ratio, excellent surface finish and the Macro Graphs after machining. Various machining parameters used to conduct an experiment are depth of cut, time pulse, current, frequency, lift time on materials like copper, brass, aluminium.
\end{abstract}

Keywords - Electrical discharge machining, Copper, Brass, Aluminum, Material removal rate, Electrodes, Metal removal.

\section{INTRODUCTION}

Electrical Discharge Machining (EDM) is the nonconventional electro thermal machining process. EDM is the process to generate the electrical spark to remove the material due to thermal energy by using electrical energy. The high voltages are used between the two electrodes by the using of electric field and the space between two electrodes has a good

\author{
Khaja Naib Rasool Shaik \\ Aeronautical Engineering \\ Kaunas University of Technology, Kaunas, Lithuania \\ Wesley Injeti \\ Mechanical Engineering \\ Mahatma Gandhi Institute of Technology, Telangana
}

strength allow to break the materials [4]. The EDM is invented in the year of 1940 and it is developed, and many documents are published to present the results for in specific cases and made a lot of experiments on different materials with certain operating conditions.

Nowadays EDM process is highly using in the large-scale industries for the precision machine of all kind of conductive materials like graphite, ceramic materials, alloys regarding hardness and EDM is used to machine the high complex shapes [5]. This process is largely applied on mould making and in construction prototypes. The objective of this paper to study the characteristic behaviour of copper, brass and aluminium using constant speed and feed by calculating the metal removal rate with different depths of cuts through electric discharge machining.

\section{LITERATURE REVIEW}

In non-traditional machining, an extensive measure of material is expelled from the raw material to get the ideal profile. The metal removal process is a highly expensive process by comparing other manufacturing processes. So, cost awareness it is highly expected to produce the product. There is no logical and financial approach ways to deal with decrease the non-productive occasions however there are extensive conceivable outcomes in reducing the machining time without reducing the nature of the machined product [6]. In recent days more priority is given in MRR, dimensional accuracy for products by the industry and they need to select the parameters to satisfy the customer requirements. Because of high speculation and machining cost of nonconventional machines, there is an effective need to work the machines as productively as conceivable to get the necessary compensation. The expense of machining is a kind of sensitive to select of machining factors [7]. 


\section{International Journal of Engineering Applied Sciences and Technology, 2019 \\ Vol. 4, Issue 8, ISSN No. 2455-2143, Pages 243-254 \\ Published Online December 2019 in IJEAST (http://www.ijeast.com)}

With the advancement and developments in new technologies, low weight- high strength and high hardness and temperature resistant materials have been developed for special applications like aerospace, automobile, medical etc. Since the presentation of the Wire Electric Discharge Machining (WEDM) process, it has developed from a straightforward method for making apparatuses and bites the dust to the best option of delivering smaller scale leaves behind the most noteworthy level of dimensional precision and surface completion [8]. WEDM is a complex machining process constrained by an enormous number of procedure parameters, for example, the beat length release recurrence and releases current force, wire electrode speed, dielectric flow rate etc. and small variations can be effective in the matching performance [9]. From the detailed information, WEDM parameters influence on output characteristics are available before shaping the material and it is a useful application. This literature reviews the research work with an attempt to understand and interpret the previous work on different aspects related to EDM/WEDM. The literature subsequently reviewed under different categories

\section{EXPERIMENTAL SETUP AND PROCESS}

The machining is carried out on Electronica C-425 EDM setup. Brass, Copper and Mild steel are used as work material with the copper electrode and spo oil as dielectric oil [10]. Experiments were performed using Electronica C-425 EDM. Copper material is used as an electrode. Spo oil is used as a dielectric fluid in this experiment. The experiment is conducted using different process parameters like peak current and pulse on time, pulse off time, gap, sensitivity, resistance, duty cycle, impulse current, bi pulse current, spark time, lift time [11].

The different work materials used to find out the material removal rate are Brass, Copper and Mild steel. The MRR is evaluated for each removal condition by evaluating the amount of material specimen removed and the time taken to remove the material [12].

Machining experiments for determining the metal removal rate will be carried out by setting voltage in the range of 120-200v, the discharge current in the range of 6.0 to $18.0 \mathrm{~A}$, the pulse duration in the range of $30-90 \mu \mathrm{s}$, and the gap between the electrode and workpiece in the range of 1-20 [13].

Once when the required parameters are chosen and set, the machining starts [14]. Either the machining time or the depth of cut is made as a fixed parameter and accordingly, the readings are noted down. if the depth of cut is made fixed, then the time taken is noted and if the time is made fixed, the depth of cut is fixed. Spo oil is a combination of hydrated water, kerosene and glycerine. As the electrode moves up and down, due to the contact of the workpiece and electrode, the current flows and material are removed which is called pulse on time [15]. When the electrode moves away from metal, the current doesn't flow and the removed material is washed away with the help of dielectric fluid, this stage is called the pulse of time. In this way the removal of the metal takes place [16].

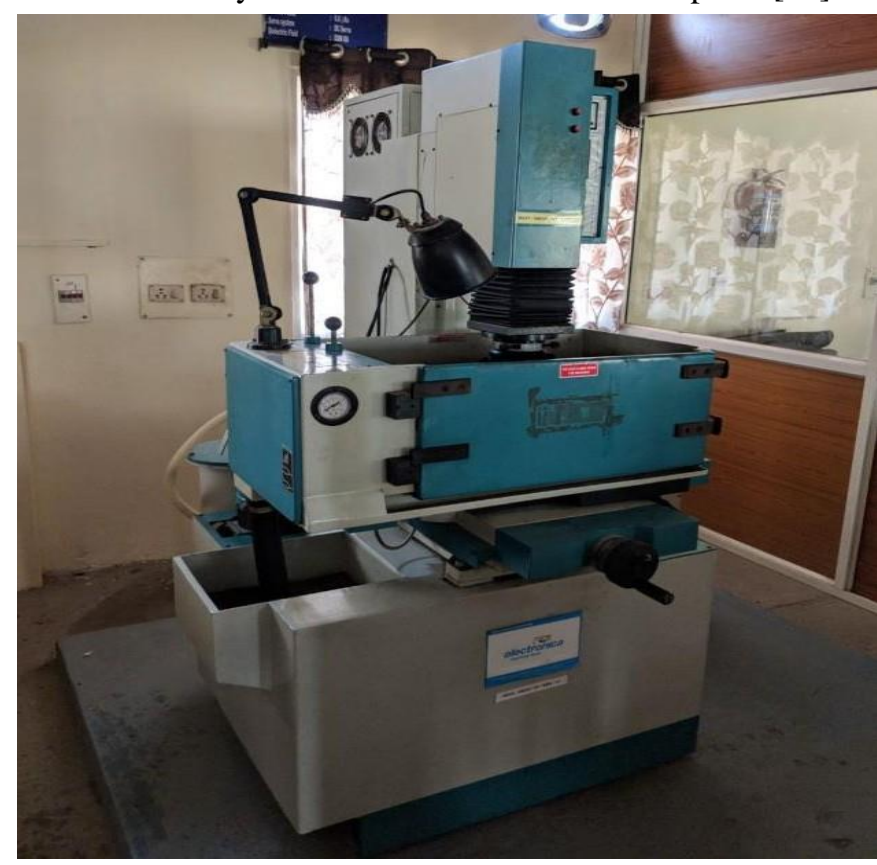

Fig. 1 EDM machine

\section{MATERIAL SELECTION}

In this case, we selected the three different materials with different parameters like brass, aluminium and copper. The materials selected because of in recent days the large-scale industries are using these kind materials because these materials are almost using in the composition of every material and so many researches are investigation on about their physical and mechanical properties to make the new composition of the materials. The physical properties of the materials shown in the below:

Table 1. Physical properties of brass

\begin{tabular}{|c|c|}
\hline Density g/cm & $8.470 \mathrm{~g} / \mathrm{cm}^{3}$ \\
\hline Melting range ${ }^{3} \mathrm{c}$ & $\begin{array}{c}900 \text { to } 940 \\
{ }^{\circ} \mathrm{C}\end{array}$ \\
\hline Specific heat J/gm. K & 0.380 \\
\hline Resistivity ohm.m & $5.9 \times 10^{-8}$ \\
\hline Temperature coefficient $\left(1 /{ }^{\circ} \mathrm{C}\right)$ & $1.5 \times 10^{-3}$ \\
\hline
\end{tabular}

Table 2. Physical properties of copper

\begin{tabular}{|c|c|}
\hline Density $\mathrm{g} / \mathrm{cm}^{3}$ & $8.96 \mathrm{~g} / \mathrm{cm}^{3}$ \\
\hline Melting range ${ }^{0} \mathrm{c}$ & $1,085^{\circ} \mathrm{C}$ \\
\hline Specific heat J/gm. C & 0.385 \\
\hline
\end{tabular}


International Journal of Engineering Applied Sciences and Technology, 2019

Vol. 4, Issue 8, ISSN No. 2455-2143, Pages 243-254

Published Online December 2019 in IJEAST (http://www.ijeast.com)

\begin{tabular}{|c|c|}
\hline Resistivity ohm.m & $1.724 \times 10^{-8}$ \\
\hline Temperature coefficient $\left(1 /{ }^{0} \mathrm{C}\right)$ & $4.29 \times 10^{-3}$ \\
\hline
\end{tabular}

Table 3. Physical properties of aluminium

\begin{tabular}{|c|c|}
\hline Density $\mathrm{g} / \mathrm{cm}^{3}$ & $2.75 \mathrm{~g} / \mathrm{cm}^{3}$ \\
\hline Melting range ${ }^{0} \mathrm{c}$ & $660.3^{\circ} \mathrm{C}$ \\
\hline Specific heat $\mathrm{J} / \mathrm{gm} . \mathrm{C}$ & 0.900 \\
\hline Resistivity ohm.m & $2.82 \times 10^{-8}$ \\
\hline Temperature coefficient $\left(1 /{ }^{\circ} \mathrm{C}\right)$ & 0.00427 \\
\hline
\end{tabular}

\section{EXPERIMENTAL CONDITIONS}

In the experimental conditions, two different stages are used with 6 experiments. In each stage, 3 experiments are made and those are shown in the below figure:

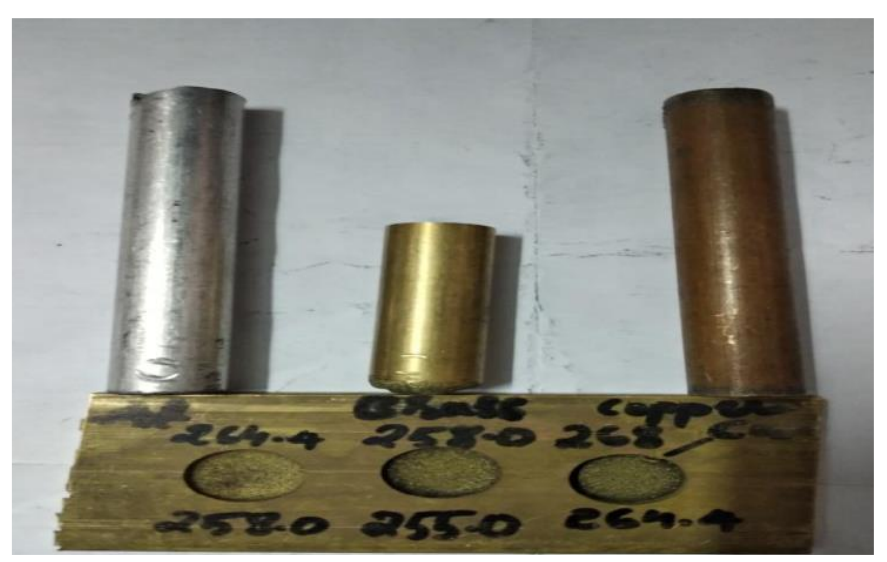

Fig 2. Brass as specimen and copper, brass, aluminium as electrodes

\section{Stage-1}

Experiment 1: Brass as a specimen

1. Copper as Electrode

2. Brass as Electrode

3. Aluminium as Electrode

Experiment 2: Copper as a specimen

1. Copper as electrode

2. Brass as electrode

3. Aluminium as electrode

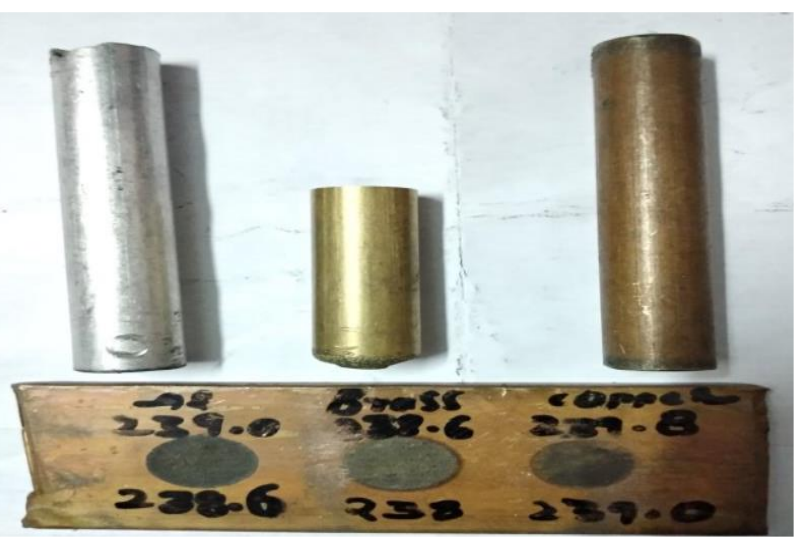

Fig 3. Copper as specimen and copper, brass, aluminum as electrodes

Experiment 3: Aluminium as Specimen

1. Copper as Electrode

2. Brass as Electrode

3. Aluminum as Electrode

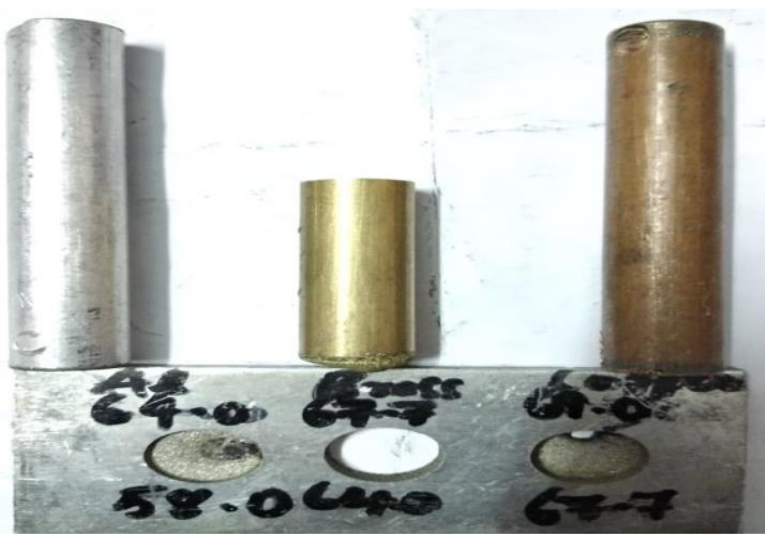

Figure 4. Aluminium as specimen and copper, brass, aluminium as electrodes

Table 4. Stage 1 parameters for machining

\begin{tabular}{|c|c|}
\hline Resistance $(\Omega)$ & 63 \\
\hline Duty cycle $(7)$ & 9 \\
\hline Impulse (amps) & 10 \\
\hline Bi impulse (amps) & 3 \\
\hline Sparking time(secs) & 2 \\
\hline Lift time (secs) & 2 \\
\hline Gap (v) & 10 \\
\hline Sensation & 20 \\
\hline
\end{tabular}

\section{Stage-2}

Experiment -4: Brass as specimen

1. Copper as Electrode

2. Brass as Electrode

3. Aluminum as Electrode 


\section{International Journal of Engineering Applied Sciences and Technology, 2019 \\ Vol. 4, Issue 8, ISSN No. 2455-2143, Pages 243-254 \\ Published Online December 2019 in IJEAST (http://www.ijeast.com)}

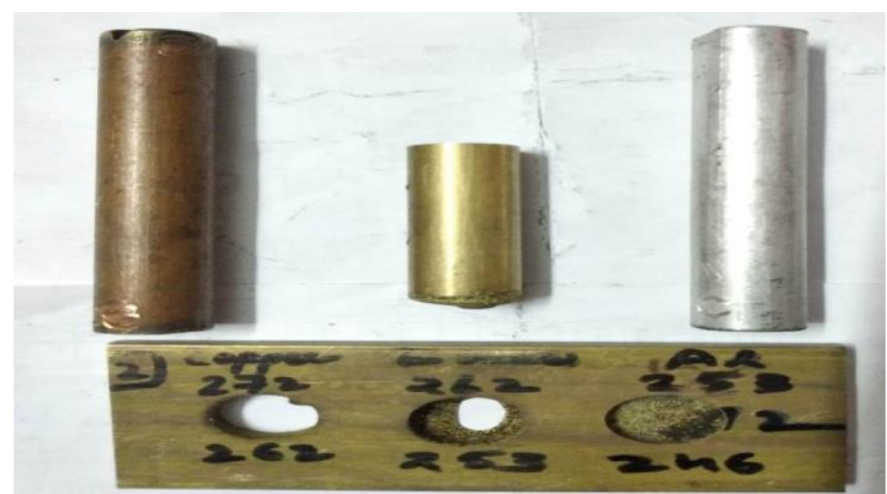

Fig 5. Brass as specimen copper, brass, aluminum as electrodes

Experiment-5: Copper as Specimen

1. Copper as Electrode

2. Brass as Electrode

3. Aluminum as Electrode

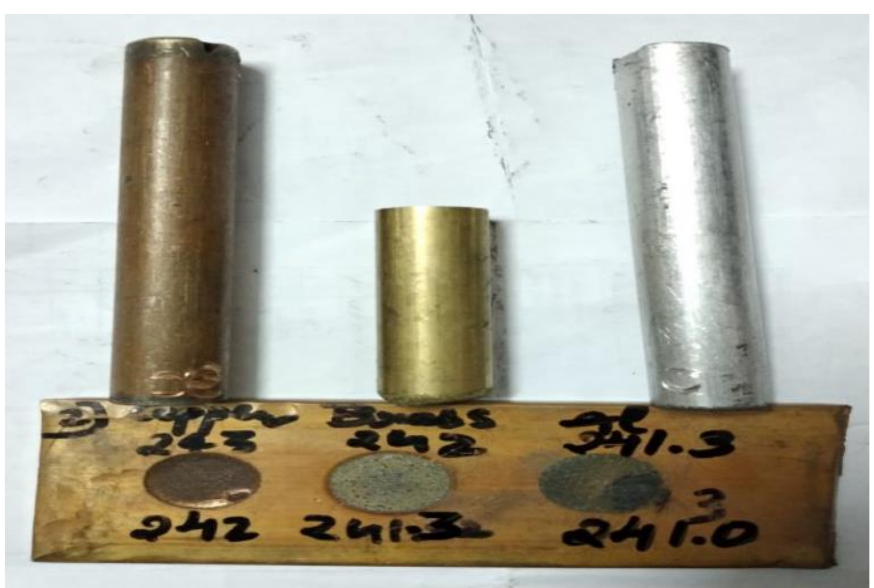

Fig 6. Copper as Specimen and copper, brass, aluminum as electrodes

Experiment-6: Aluminium as Specimen

1. Copper as Electrode

2. Brass as Electrode

3. Aluminum as Electrode

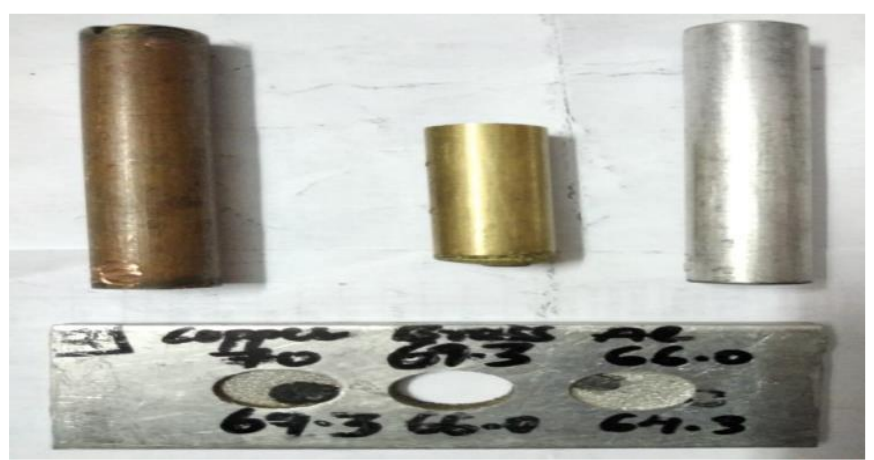

Fig 7. Aluminium as Specimen and copper, brass, aluminium as electrodes
Table 5. Stage 2 parameters for machining

\begin{tabular}{|c|c|}
\hline Resistance $(\Omega)$ & 63 \\
\hline Duty cycle $(7)$ & 9 \\
\hline Impulse $(\mathrm{amps})$ & 19 \\
\hline Bi impulse $(\mathrm{amps})$ & 3 \\
\hline Sparking time $(\mathrm{secs})$ & 5 \\
\hline Lift time $(\mathrm{secs})$ & 2 \\
\hline Gap (v) & 15 \\
\hline Sensation & 20 \\
\hline
\end{tabular}

From the above table, some parameters are changed like impulse and sparking time.

\section{Specifications:}

Electrode Diameter-16mm.

Length-100mm.

Specimen length100mm*Width50mm*Thickness5mm.

\section{Grades of materials used:}

Copper-C106/CW024A.

Aluminium-Alloy 2024.

Brass C38500.

\section{RESULTS AND DISCUSSION}

A conclusion, In this case, the different parameters are used in stage 1 and stage 2 as shown in table 4 and 5 and each specimen is used to make the results for each electrode and results are compared. In each stage, each material is calculated with each electrode to make a proper comparison.

In stage 2 experiments some experimental parameters are changed and from these results, MRR is little high value in stage 2 by comparing the results from stage 1 . From all results, MRR is high in both stage 1 and sate2.

\section{Stage-1: Brass as specimen \\ Experiment-1: (A)Copper as electrode}

Table 6. Results for copper as electrode

\begin{tabular}{|c|c|}
\hline $\begin{array}{c}\text { The initial weight of workpiece before } \\
\text { machining }\end{array}$ & $268 \mathrm{gms}$ \\
\hline $\begin{array}{c}\text { The final weight of workpiece before } \\
\text { machining }\end{array}$ & $264.4 \mathrm{gms}$ \\
\hline Time is taken for the machining to be done & 2 \\
\hline MRR & $30 \mathrm{~mm}^{3} / \mathrm{min}$ \\
\hline Surface roughness (Ra) & $2.5 \mu \mathrm{m}$ \\
\hline Signal to Noise Ratio & 0.3174 \\
\hline
\end{tabular}


(B)Brass as electrode

Table 7. Results for brass as electrode

\begin{tabular}{|c|c|}
\hline $\begin{array}{c}\text { The initial weight of workpiece before } \\
\text { machining }\end{array}$ & $258 \mathrm{gms}$ \\
\hline $\begin{array}{c}\text { The final weight of workpiece before } \\
\text { machining }\end{array}$ & $255 \mathrm{gms}$ \\
\hline Time is taken for the machining to be done & 2 \\
\hline MRR & $25 \mathrm{~mm}^{3} / \mathrm{min}$ \\
\hline Surface roughness (Ra) & $5.70 \mu \mathrm{m}$ \\
\hline Signal to Noise Ratio & 0.3174 \\
\hline
\end{tabular}

(C)Aluminum as electrode

Table 8. Results for aluminum as electrode

\begin{tabular}{|c|c|}
\hline $\begin{array}{c}\text { The initial weight of workpiece before } \\
\text { machining }\end{array}$ & $264.4 \mathrm{gms}$ \\
\hline $\begin{array}{c}\text { The final weight of workpiece before } \\
\text { machining }\end{array}$ & $258 \mathrm{gms}$ \\
\hline Time is taken for the machining to be done & 2 \\
\hline MRR & $53.3 \mathrm{~mm}^{3} / \mathrm{min}$ \\
\hline Surface roughness (Ra) & $2.75 \mu \mathrm{m}$ \\
\hline Signal to Noise Ratio & 0.3174 \\
\hline
\end{tabular}

\section{Experiment-2: Copper as specimen}

(A)Copper as electrode

Table 9. Results for copper as electrode

\begin{tabular}{|c|c|}
\hline $\begin{array}{c}\text { The initial weight of workpiece before } \\
\text { machining }\end{array}$ & $239.8 \mathrm{gms}$ \\
\hline $\begin{array}{c}\text { The final weight of workpiece before } \\
\text { machining }\end{array}$ & $239 \mathrm{gms}$ \\
\hline Time is taken for the machining to be done & 2 \\
\hline MRR & $6.6 \mathrm{~mm}^{3} / \mathrm{min}$ \\
\hline Surface roughness $(\mathrm{Ra})$ & $2.24 \mu \mathrm{m}$ \\
\hline Signal to Noise Ratio & 3.15 \\
\hline
\end{tabular}

B)Brass as electrode

Table 10. Results for brass as electrode

\begin{tabular}{|c|c|}
\hline $\begin{array}{l}\text { The initial weight of workpiece before } \\
\text { machining }\end{array}$ & 238.6gms \\
\hline $\begin{array}{l}\text { The final weight of workpiece before } \\
\text { machining }\end{array}$ & $238 \mathrm{gms}$ \\
\hline Time is taken for the machining to be done & 2 \\
\hline MRR & $5 \mathrm{~mm}^{3} / \mathrm{min}$ \\
\hline Surface roughness $(\mathrm{Ra})$ & $\begin{array}{c}0.7175 \\
\mu \mathrm{m}\end{array}$ \\
\hline Signal to Noise Ratio & 0.3174 \\
\hline
\end{tabular}

(C)Aluminium as electrode

Table 11. Results for aluminium as electrode

\begin{tabular}{|c|c|}
\hline $\begin{array}{c}\text { The initial weight of workpiece before } \\
\text { machining }\end{array}$ & $239 \mathrm{gms}$ \\
\hline $\begin{array}{c}\text { The final weight of workpiece before } \\
\text { machining }\end{array}$ & $238.6 \mathrm{gms}$ \\
\hline Time is taken for the machining to be done & 2 \\
\hline MRR & $3.3 \mathrm{~mm}^{3} / \mathrm{min}$ \\
\hline Surface roughness (Ra) & $1.121 \mu \mathrm{m}$ \\
\hline Signal to Noise Ratio & 0.3174 \\
\hline
\end{tabular}

Experiment-3: Aluminum as a specimen

(A)Copper as electrode

Table 12. Results for copper as an electrode

\begin{tabular}{|c|c|}
\hline $\begin{array}{c}\text { The initial weight of workpiece before } \\
\text { machining }\end{array}$ & $69 \mathrm{gms}$ \\
\hline $\begin{array}{c}\text { The final weight of workpiece before } \\
\text { machining }\end{array}$ & $67.7 \mathrm{gms}$ \\
\hline Time is taken for the machining to be done & 2 \\
\hline MRR & $10 \mathrm{~mm}^{3} / \mathrm{min}$ \\
\hline Surface roughness (Ra) & $2.935 \mu \mathrm{m}$ \\
\hline Signal to Noise Ratio & 3.15 \\
\hline
\end{tabular}

(B)Brass as electrode

Table 13. Results for brass as electrode

\begin{tabular}{|c|c|}
\hline $\begin{array}{c}\text { The initial weight of workpiece before } \\
\text { machining }\end{array}$ & $268 \mathrm{gms}$ \\
\hline $\begin{array}{c}\text { The final weight of workpiece before } \\
\text { machining }\end{array}$ & $264.4 \mathrm{gms}$ \\
\hline Time is taken for the machining to be done & 2 \\
\hline MRR & $30 \mathrm{~mm}^{3} / \mathrm{min}$ \\
\hline Surface roughness (Ra) & $2.5 \mu \mathrm{m}$ \\
\hline Signal to Noise Ratio & 0.3174 \\
\hline
\end{tabular}




\section{International Journal of Engineering Applied Sciences and Technology, 2019 \\ Vol. 4, Issue 8, ISSN No. 2455-2143, Pages 243-254 \\ Published Online December 2019 in IJEAST (http://www.ijeast.com)}

(C)Aluminium as electrode

Table 14. Results for aluminium as electrode

\begin{tabular}{|c|c|}
\hline $\begin{array}{c}\text { The initial weight of workpiece before } \\
\text { machining }\end{array}$ & $64 \mathrm{gms}$ \\
\hline $\begin{array}{c}\text { The final weight of workpiece before } \\
\text { machining }\end{array}$ & $58 \mathrm{gms}$ \\
\hline Time is taken for the machining to be done & 2 \\
\hline MRR & $50 \mathrm{~mm}^{3} / \mathrm{min}$ \\
\hline Surface roughness (Ra) & $2.234 \mu \mathrm{m}$ \\
\hline Signal to Noise Ratio & 0.3174 \\
\hline
\end{tabular}

\section{Stage-2:}

It is observed that signal to noise ratio and surface roughness is constant although the parameters have been changed. By the changing of properties and it will variant in stage 2 results.

Experiment- 4: Brass as the specimen

(A)Copper as electrode

Table 15. Results for copper as an electrode

\begin{tabular}{|c|c|}
\hline $\begin{array}{c}\text { The initial weight of workpiece before } \\
\text { machining }\end{array}$ & $272 \mathrm{gms}$ \\
\hline $\begin{array}{c}\text { The final weight of workpiece before } \\
\text { machining }\end{array}$ & $262 \mathrm{gms}$ \\
\hline Time is taken for the machining to be done & $30 \mathrm{~min}$ \\
\hline MRR & $333.33 \mathrm{~mm}^{3} / \mathrm{min}$ \\
\hline Surface roughness (Ra) & $2.24 \mu \mathrm{m}$ \\
\hline Signal to Noise Ratio & 3.15 \\
\hline
\end{tabular}

(B)Brass as electrode

Table 16. Results for brass as electrode

\begin{tabular}{|c|c|}
\hline $\begin{array}{c}\text { The initial weight of workpiece before } \\
\text { machining }\end{array}$ & $262 \mathrm{gms}$ \\
\hline $\begin{array}{c}\text { The final weight of workpiece before } \\
\text { machining }\end{array}$ & $253 \mathrm{gms}$ \\
\hline Time is taken for the machining to be done & $30 \mathrm{~min}$ \\
\hline MRR & $300 \mathrm{~mm}^{3} / \mathrm{min}$ \\
\hline Surface roughness $(\mathrm{Ra})$ & $2.24 \mu \mathrm{m}$ \\
\hline Signal to Noise Ratio & 3.15 \\
\hline
\end{tabular}

(C)Aluminium as electrode

Table 17. Results for aluminium as electrode

\begin{tabular}{|c|c|}
\hline $\begin{array}{c}\text { The initial weight of workpiece before } \\
\text { machining }\end{array}$ & $253 \mathrm{gms}$ \\
\hline $\begin{array}{c}\text { The final weight of workpiece before } \\
\text { machining }\end{array}$ & $246 \mathrm{gms}$ \\
\hline Time is taken for the machining to be done & $30 \mathrm{~min}$ \\
\hline MRR & $233.3 \mathrm{~mm}^{3} / \mathrm{min}$ \\
\hline Surface roughness (Ra) & $1.121 \mu \mathrm{m}$ \\
\hline Signal to Noise Ratio & 0.3174 \\
\hline
\end{tabular}

\section{Experiment- 5: Copper as a specimen}

(A)Copper as electrode

Table 18. Results for copper as an electrode

\begin{tabular}{|c|c|}
\hline $\begin{array}{c}\text { The initial weight of workpiece before } \\
\text { machining }\end{array}$ & $243 \mathrm{gms}$ \\
\hline $\begin{array}{c}\text { The final weight of workpiece before } \\
\text { machining }\end{array}$ & $242 \mathrm{gms}$ \\
\hline Time is taken for the machining to be done & $30 \mathrm{~min}$ \\
\hline MRR & $33.33 \mathrm{~mm}^{3} / \mathrm{min}$ \\
\hline Surface roughness (Ra) & $1.121 \mu \mathrm{m}$ \\
\hline Signal to Noise Ratio & 0.3174 \\
\hline
\end{tabular}

(B)Brass as electrode

Table 19. Results for brass as electrode

\begin{tabular}{|c|c|}
\hline $\begin{array}{c}\text { The initial weight of workpiece before } \\
\text { machining }\end{array}$ & $242 \mathrm{gms}$ \\
\hline The final weight of workpiece before machining & $241.3 \mathrm{gms}$ \\
\hline Time is taken for the machining to be done & $30 \mathrm{~min}$ \\
\hline MRR & $\begin{array}{c}25.33 \mathrm{~mm}^{3} / \\
\mathrm{min}\end{array}$ \\
\hline Surface roughness (Ra) & $1.121 \mu \mathrm{m}$ \\
\hline Signal to Noise Ratio & 0.3174 \\
\hline
\end{tabular}




\section{International Journal of Engineering Applied Sciences and Technology, 2019 \\ Vol. 4, Issue 8, ISSN No. 2455-2143, Pages 243-254 \\ Published Online December 2019 in IJEAST (http://www.ijeast.com)}

(C)Aluminium as electrode

Table 20. Results for aluminium as electrode

\begin{tabular}{|c|c|}
\hline $\begin{array}{c}\text { The initial weight of workpiece before } \\
\text { machining }\end{array}$ & $241.3 \mathrm{gms}$ \\
\hline $\begin{array}{c}\text { The final weight of workpiece before } \\
\text { machining }\end{array}$ & $241 \mathrm{gms}$ \\
\hline Time is taken for the machining to be done & $30 \mathrm{~min}$ \\
\hline MRR & $10 \mathrm{~mm}^{3} / \mathrm{min}$ \\
\hline Surface roughness (Ra) & $1.121 \mu \mathrm{m}$ \\
\hline Signal to Noise Ratio & 0.3174 \\
\hline
\end{tabular}

In experiment 5 the MRR value is low by comparing the materials electrodes copper is having the high MRR and aluminium is low MRR

\section{Experiment- 6: Aluminum as a specimen}

(A)Brass as electrode

Table 21. Results for brass as electrode

\begin{tabular}{|c|c|}
\hline $\begin{array}{c}\text { The initial weight of workpiece before } \\
\text { machining }\end{array}$ & $67.3 \mathrm{gms}$ \\
\hline $\begin{array}{c}\text { The final weight of workpiece before } \\
\text { machining }\end{array}$ & $62 \mathrm{gms}$ \\
\hline Time is taken for the machining to be done & $30 \mathrm{~min}$ \\
\hline MRR & $176.66 \mathrm{~mm}^{3} / \mathrm{min}$ \\
\hline Surface roughness (Ra) & $1.121 \mu \mathrm{m}$ \\
\hline Signal to Noise Ratio & 0.3174 \\
\hline
\end{tabular}

(B)Copper as electrode

Table 22. Results for copper as an electrode

\begin{tabular}{|c|c|}
\hline $\begin{array}{c}\text { The initial weight of workpiece before } \\
\text { machining }\end{array}$ & $70 \mathrm{gms}$ \\
\hline $\begin{array}{c}\text { The final weight of workpiece before } \\
\text { machining }\end{array}$ & $67.3 \mathrm{gms}$ \\
\hline Time is taken for the machining to be done & $30 \mathrm{~min}$ \\
\hline MRR & $90 \mathrm{~mm}^{3} / \mathrm{min}$ \\
\hline Surface roughness (Ra) & $1.121 \mu \mathrm{m}$ \\
\hline Signal to Noise Ratio & 0.3174 \\
\hline
\end{tabular}

(C)Aluminium as electrode

Table 23. Results for aluminium as electrode

\begin{tabular}{|c|c|}
\hline $\begin{array}{c}\text { The initial weight of workpiece before } \\
\text { machining }\end{array}$ & $62 \mathrm{gms}$ \\
\hline $\begin{array}{c}\text { The final weight of workpiece before } \\
\text { machining }\end{array}$ & $60.3 \mathrm{gms}$ \\
\hline Time is taken for the machining to be done & $30 \mathrm{~min}$ \\
\hline MRR & $56.66 \mathrm{~mm}^{3} / \mathrm{min}$ \\
\hline Surface roughness (Ra) & $1.121 \mu \mathrm{m}$ \\
\hline Signal to Noise Ratio & 0.3174 \\
\hline
\end{tabular}

From the above results in an aluminium, the specimen is taken the less time because pure form aluminium is the very soft material and less weight also. The aluminium is very is the very weak material when it is in the pure form. From these properties, aluminium is very easy to remove and when aluminium is mix with some other material then only it will become strong for this reason aluminium is easy to make a good composition with other materials.

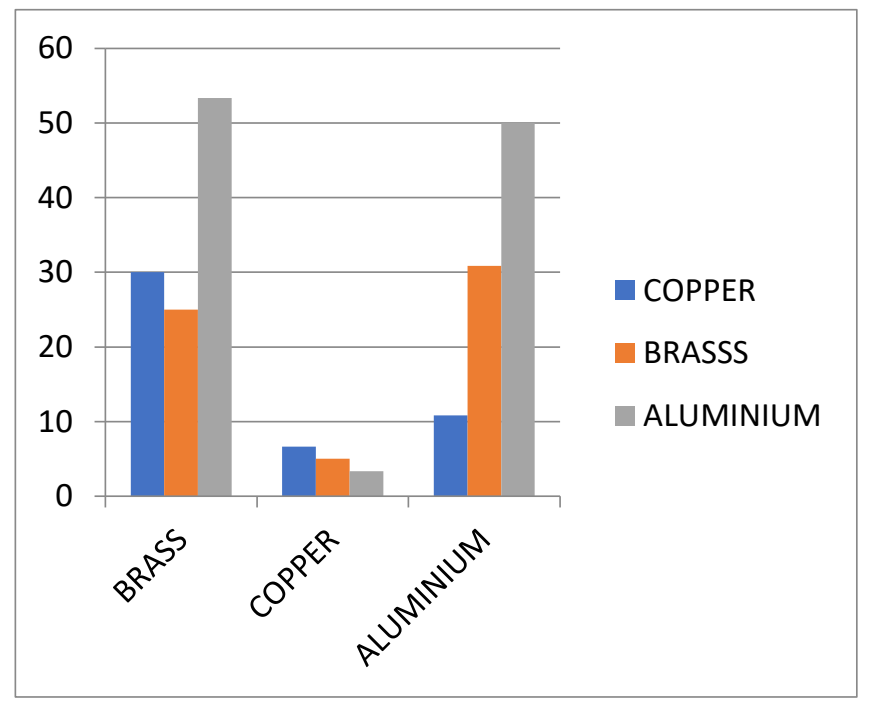

Fig 8. Graphical representation for brass, copper and aluminium in stage 1

Graph denoting Specimens on $\mathrm{X}$-axis and MRR on $\mathrm{Y}$-axis with respect to three different electrodes for a time duration of 2 hours as for stage-1 parameters. 
International Journal of Engineering Applied Sciences and Technology, 2019

Vol. 4, Issue 8, ISSN No. 2455-2143, Pages 243-254

Published Online December 2019 in IJEAST (http://www.ijeast.com)

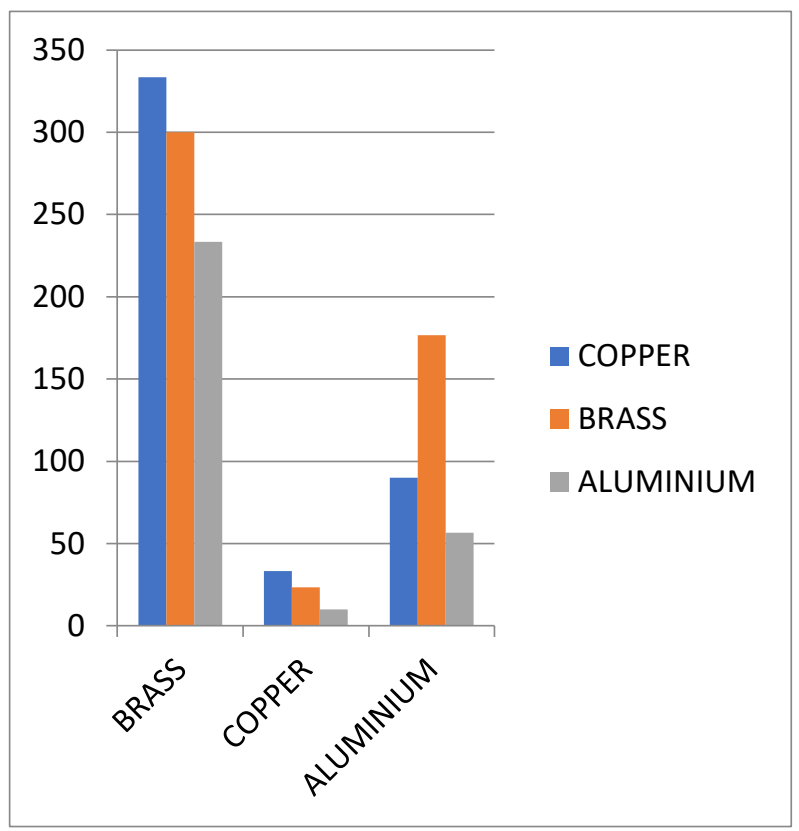

Fig 9. Graphical representation for brass, copper and aluminium in stage 2

Graph denoting Specimens on X-axis and MRR on Y-axis with respect to three different electrodes for a time duration of 30 minutes as for stage- 2 parameters.

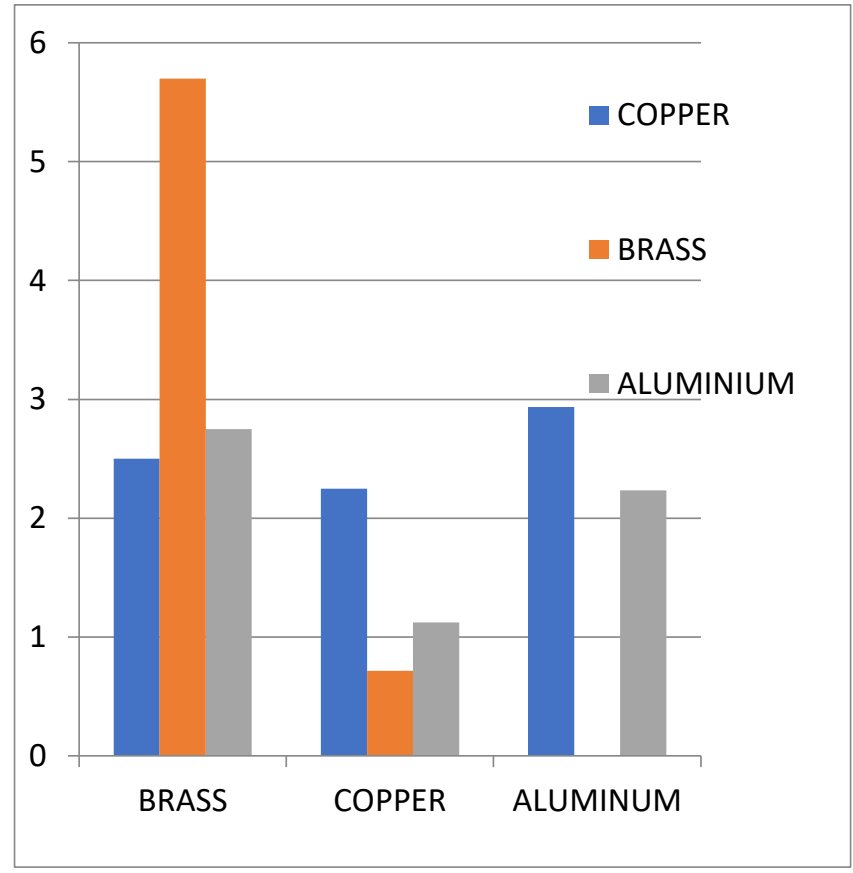

Fig 10. Graphical representation for brass, copper and aluminium in both stages.
Table 24. MRR in descending order for stage 1

\begin{tabular}{|c|c|c|}
\hline S.no & Specimen & Electrode \\
\hline 1 & Brass & Aluminium \\
\hline 2 & Aluminium & Brass \\
\hline 3 & Copper & Brass \\
\hline 4 & Brass & Brass \\
\hline 5 & Aluminium & Copper \\
\hline 6 & Copper & Copper \\
\hline 7 & Copper & Brass \\
\hline 8 & Copper & Aluminium \\
\hline 9 & Aluminium & Aluminium \\
\hline
\end{tabular}

Table 25. MRR in descending order for stage 2

\begin{tabular}{|c|c|c|}
\hline S.no & Specimen & Electrode \\
\hline 1 & Brass & Copper \\
\hline 2 & Brass & Brass \\
\hline 3 & Brass & Aluminium \\
\hline 4 & Brass & Brass \\
\hline 5 & Aluminium & Copper \\
\hline 6 & Aluminium & Copper \\
\hline 7 & Copper & Brass \\
\hline 8 & Copper & Aluminium \\
\hline 9 & Aluminium & Aluminium \\
\hline
\end{tabular}

From the above tables the comparison between the two stages of specimen and electrodes for the MRR descending order.

\section{Microscope results for Stage-1}

In this case, the metallurgical microscope is used for the inspection which is including the metals and ceramics. This microscope has capable of magnifying the image from the small object and there are some advanced techniques for the student use. The metallurgical microscope includes the total magnification and resolution.

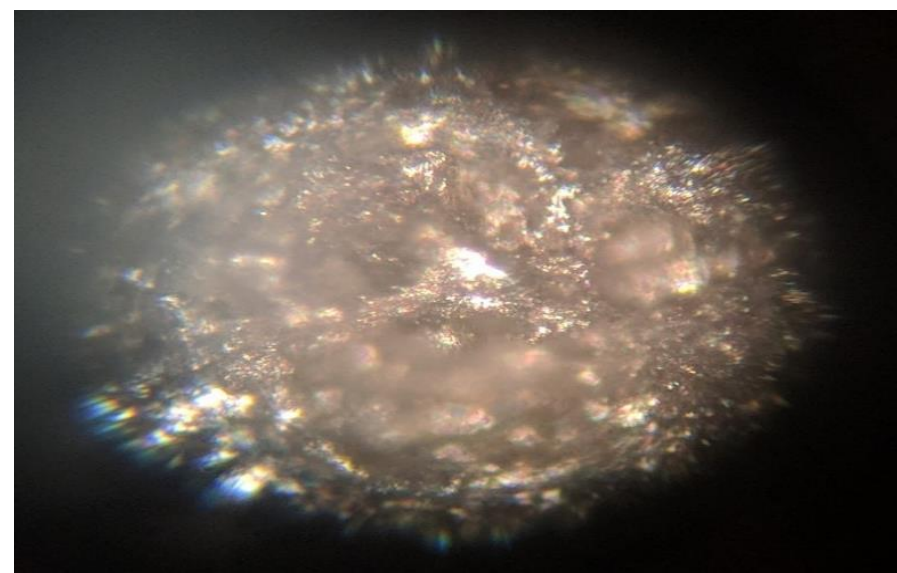

Fig 11. Aluminium specimen machined with Aluminum Electrode. 


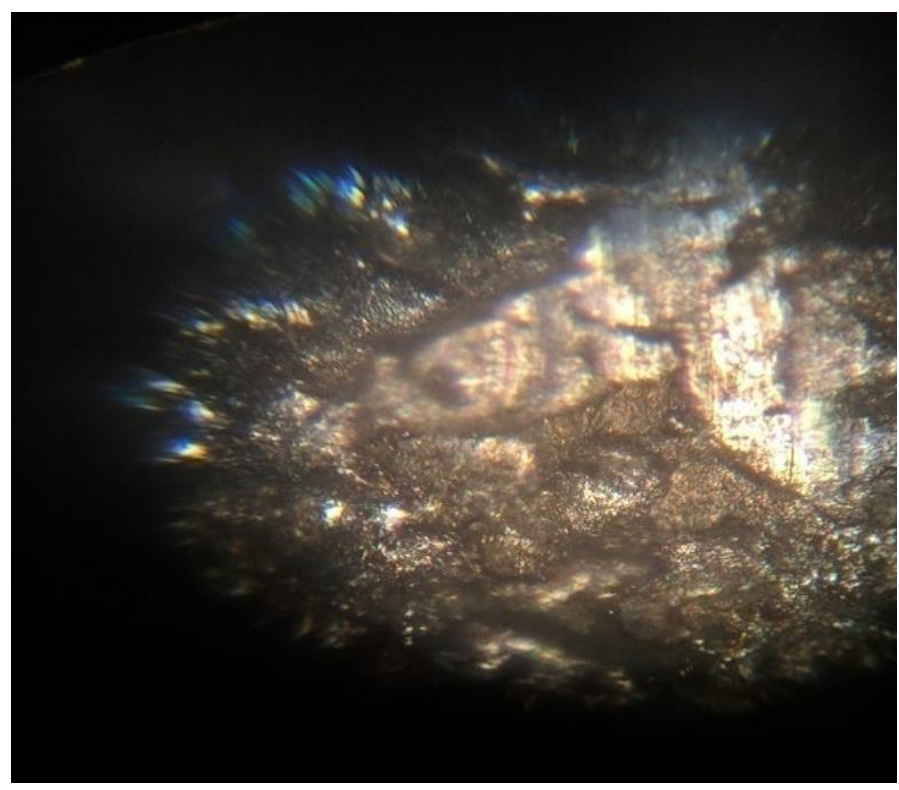

Fig 12. Aluminium specimen machined with Copper Electrode

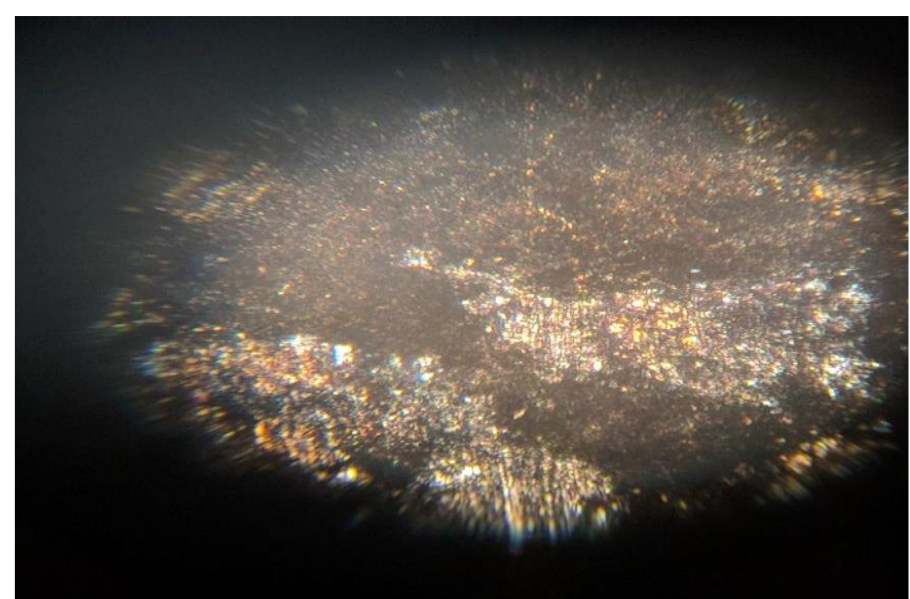

Fig 13. Copper specimen machined with Aluminium Electrode

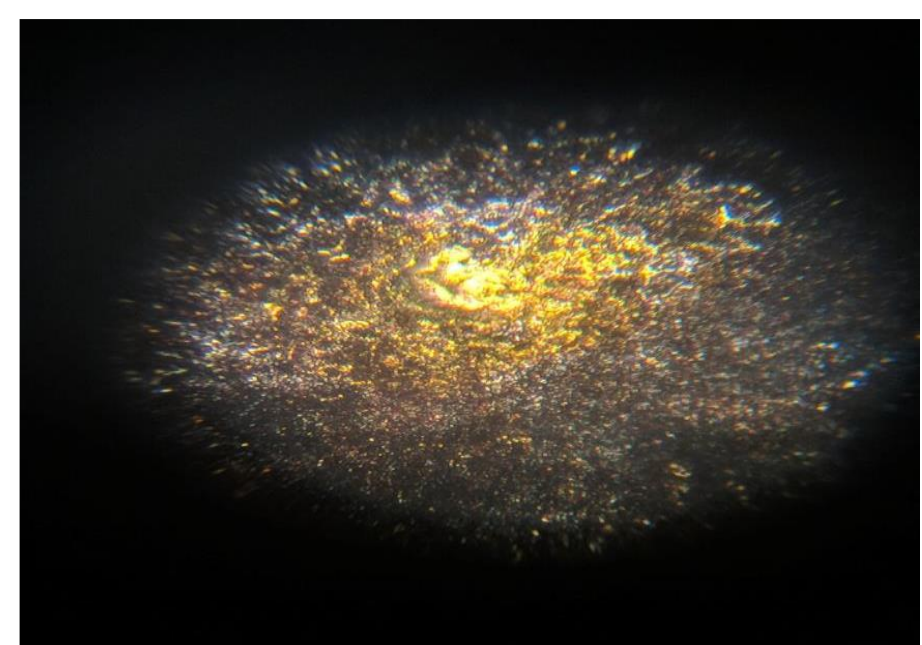

Fig 14. Copper specimen machined with Brass Electrode

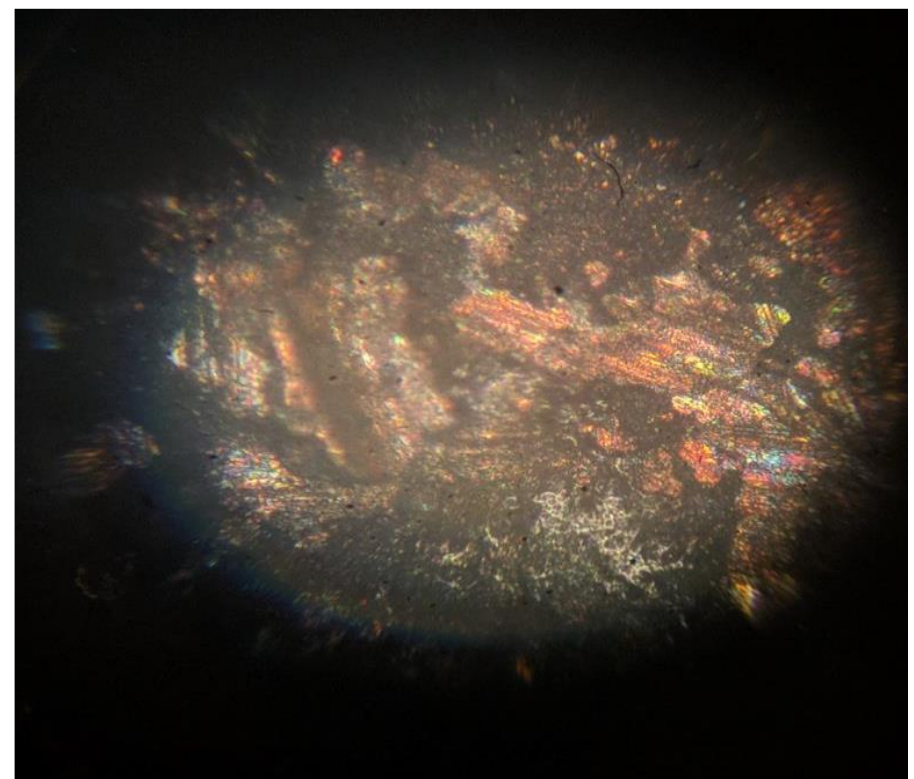

Fig 15. Copper specimen machined with Copper Electrode 


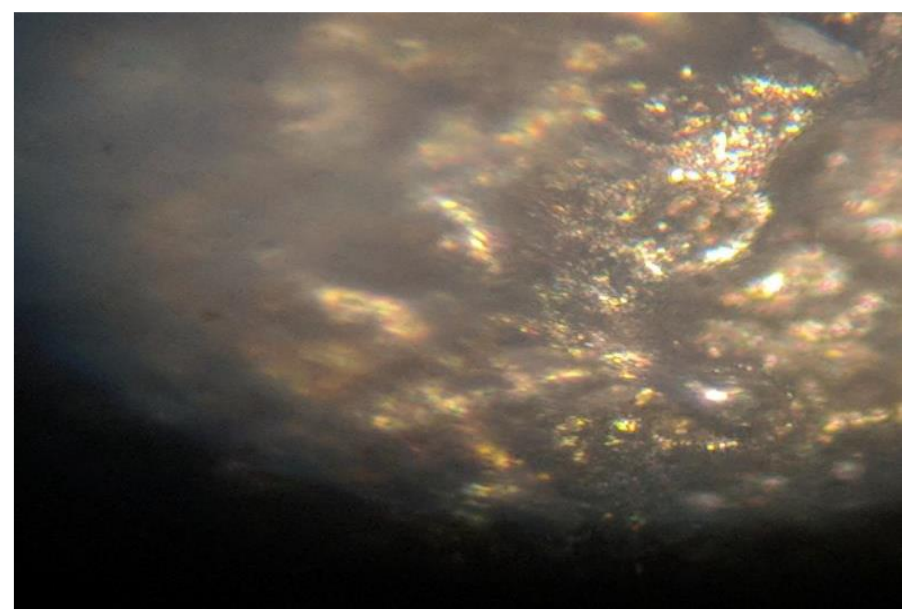

Fig 16. Brass specimen machined with Brass Electrode

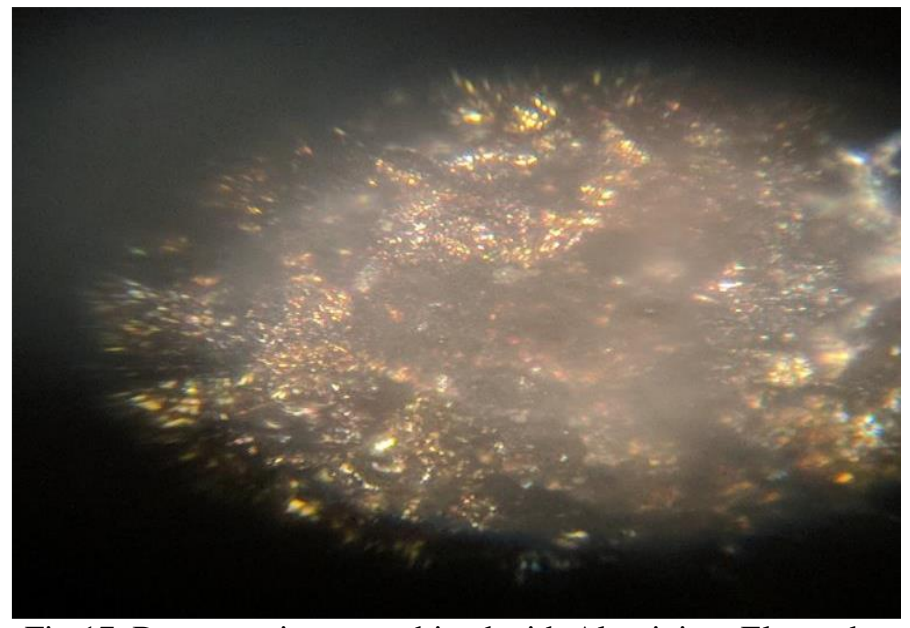

Fig 17. Brass specimen machined with Aluminium Electrode

Macroscope results for Stage-2

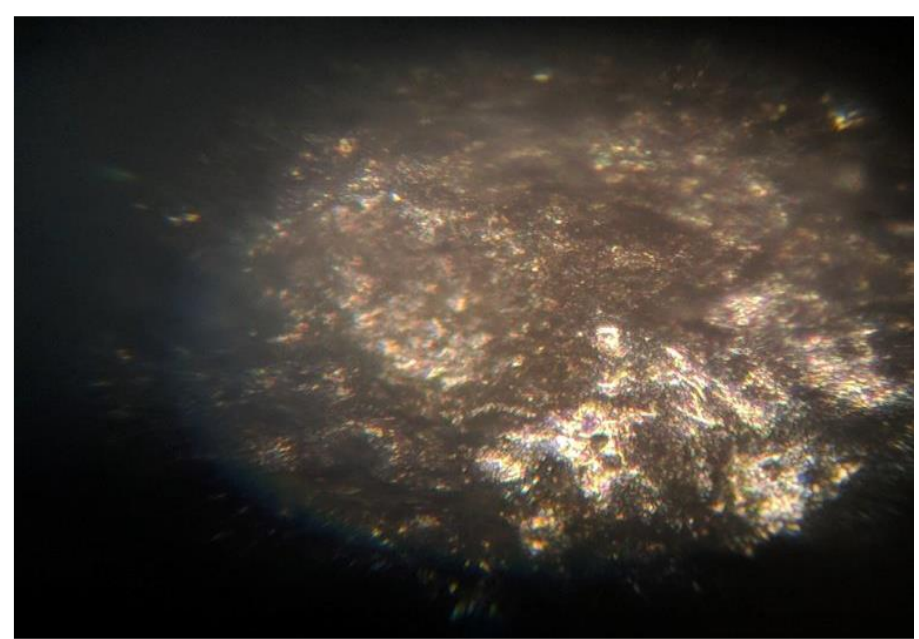

Fig 18. Aluminium specimen machined with Aluminium

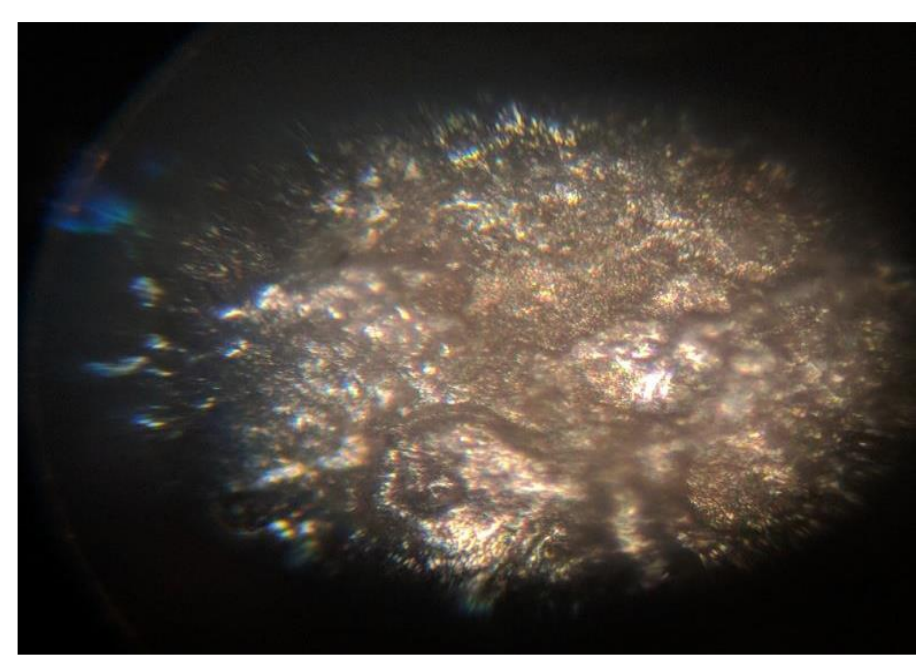

Fig 19. Aluminium specimen machined with Copper Electrode

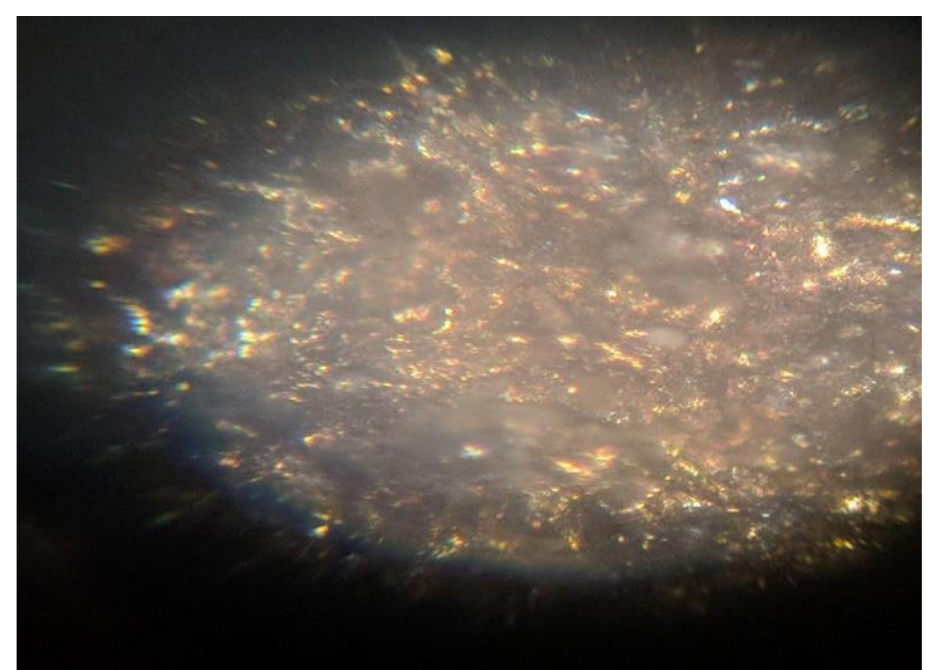

Fig 20. Brass specimen machined with Aluminium Electrode

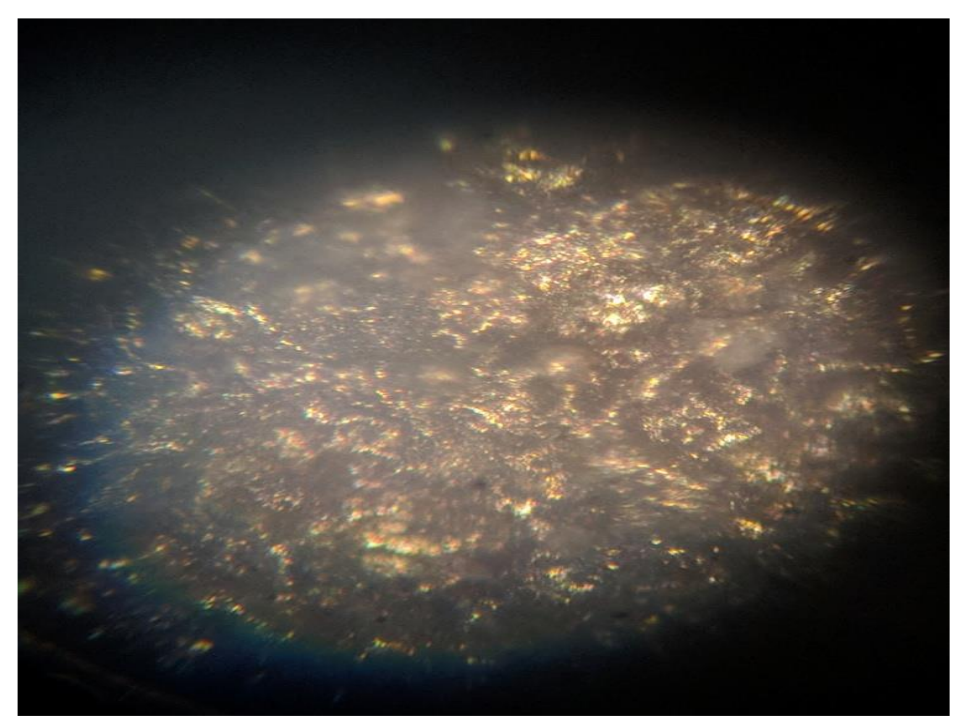

Fig 21. Brass specimen machined with Brass Electrode 


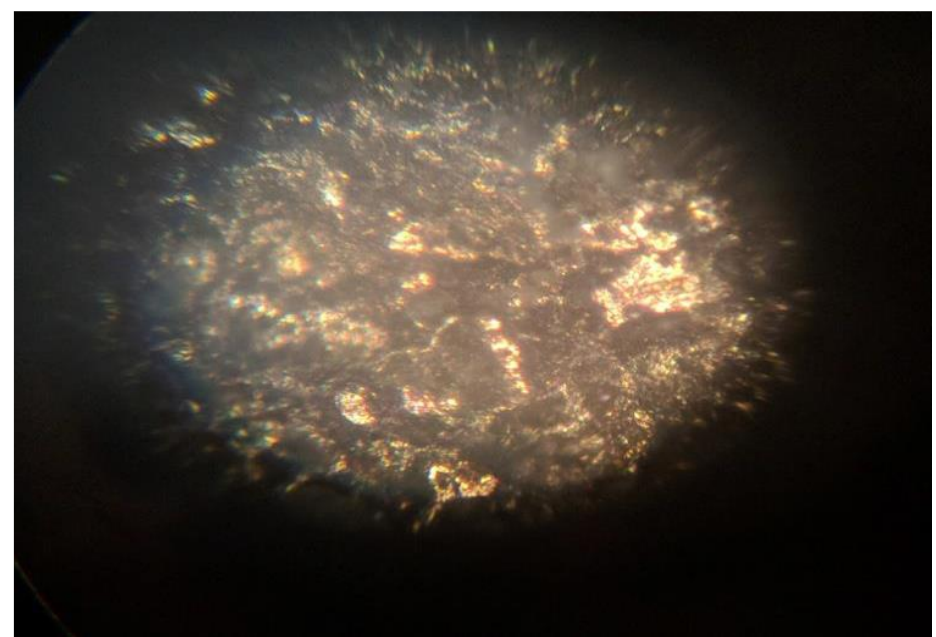

Fig 22. Brass specimen machined with Copper Electrode

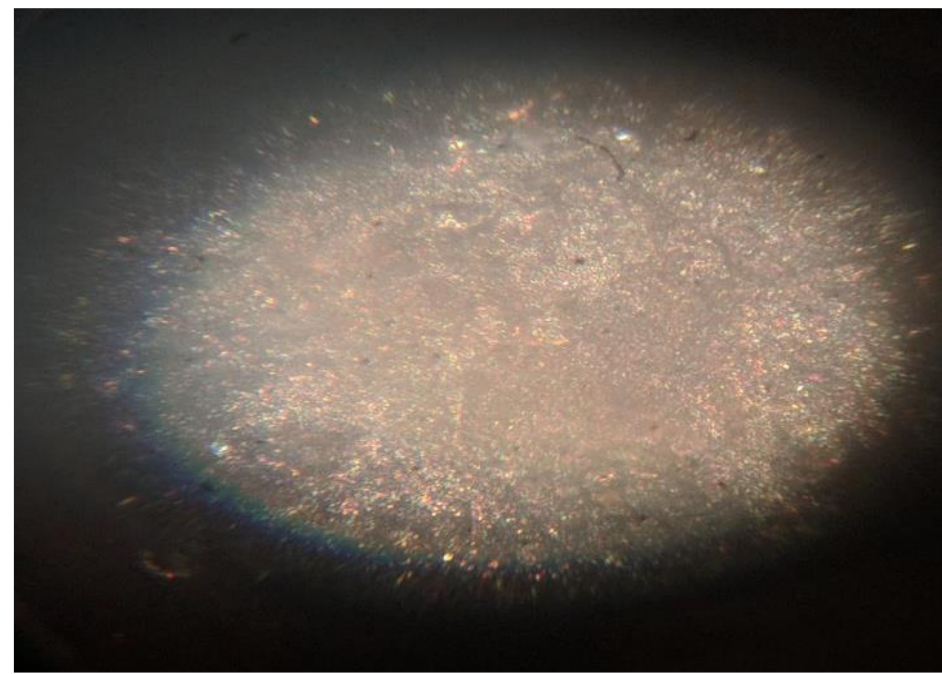

Fig 23. Copper specimen machined with Copper Electrode

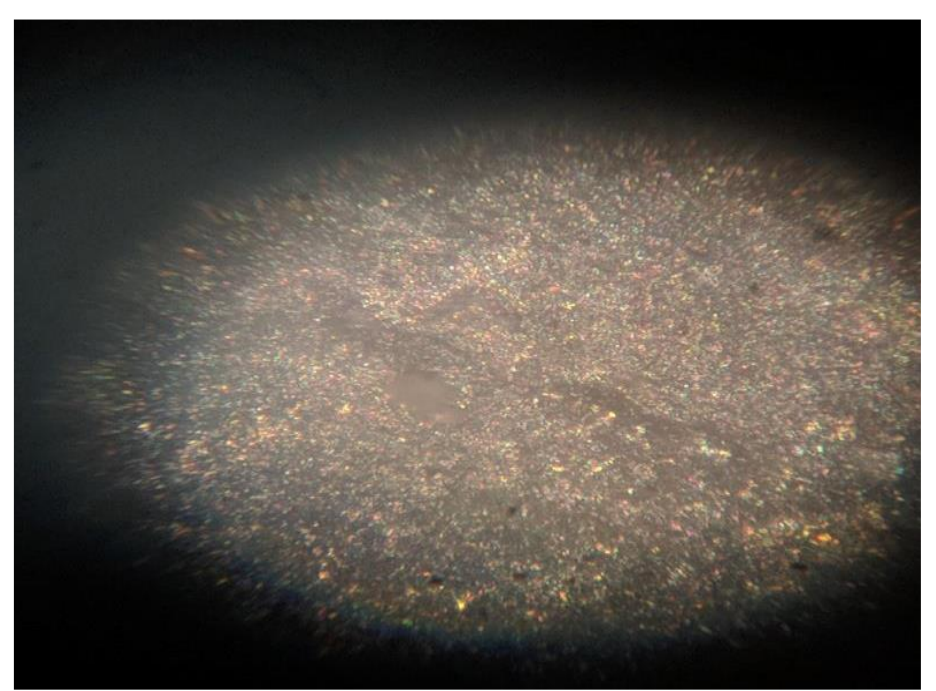

Fig 24. Copper specimen machined with Brass Electrode

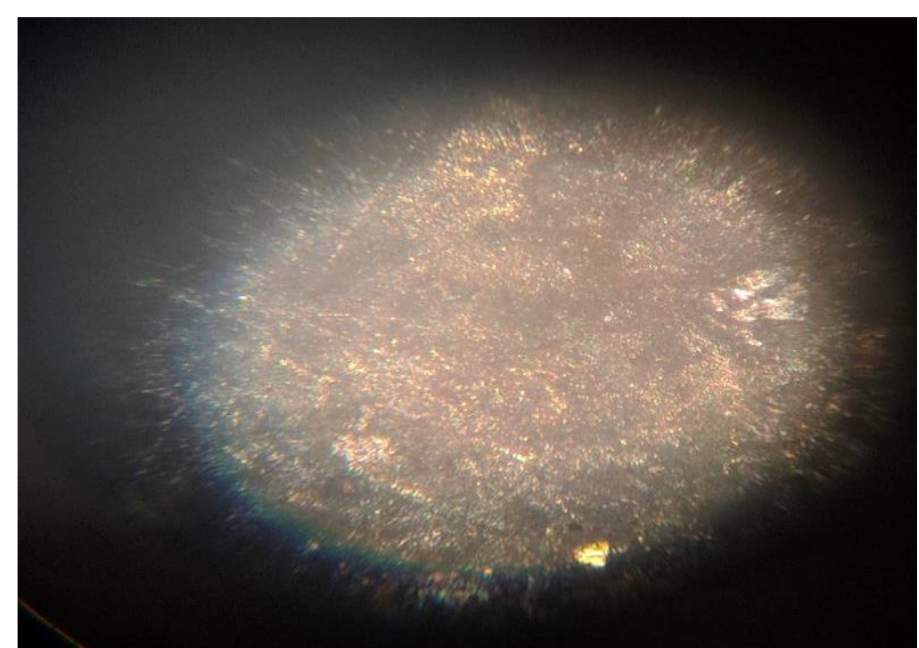

Fig 25. Copper specimen machined with Aluminum Electrode

From the results are shown for stage 1 and satge2. In both, the microscopic results are configured to compare the results.

\section{CONCLUSION}

This work has been carried out to measure the metal removal rate, surface roughness, signal to noise ratio and macro graphs of the specimens by machining Brass, Copper and Aluminium with Electric Discharge Machining using a copper, brass and aluminium electrodes.

Based on the results presented herein, we can conclude that the impulse current and time affect the metal removal rate.

The material removal rate is determined with different depth of cuts for copper, brass and aluminium and found that MRR is high for the brass specimen to aluminium electrode in stage 1 and brass specimen to the copper electrode in stage 2 . Aluminium specimen to aluminium electrode has the lowest material removal rate due to the formation of aluminium oxides. The MRR is indirectly proportional to the time to take for the machining process. It is found that Surface finish is higher in case of the copper specimen to the brass electrode with surface roughness value $\mathrm{Ra}=0.7175$ And also the lowest surface finish is obtained for Brass specimen to the brass electrode. Macro graphs are taken using the metallurgical microscope and observed after the EDM machining.

\section{REFERENCE}

[1] J.Paulo David, K.Palanikumar. (2013). Machining and machine tools Electrical discharge machining- a study on machining characteristics of WC/Co composites, pp. 135168.

[2] Nur Sheril Loke Binti iwan, Zhujin Feng, Jiger Ptel, Wayne Hung. (2016). Prediction of Material Removal Rate in Die-sinking Electrical Discharge Machining, Procedia Manufacturing, Volume 5, pp. 658-668. 


\section{International Journal of Engineering Applied Sciences and Technology, 2019 \\ Vol. 4, Issue 8, ISSN No. 2455-2143, Pages 243-254 \\ Published Online December 2019 in IJEAST (http://www.ijeast.com)}

[3] H. Poor (1985), An Introduction to Signal Detection and Estimation. New York: Springer-Verlag, ch. 4.

[4] Kansal H, Singh S and Kumar P. (2007). Technology and research developments in powder mixed electric discharge machining (PMEDM). Journal of Materials Processing Technology 184: 32-41.

[5] Kansal HK, Singh Sehijpal and Kumar P. (2007). Modeling of machining parameters in powder mixed electric discharge machining (PMEDM) of Al-10\% SiCP metal matrix composites. Journal of Materials Processing Technology 1:396-411.

[6] Kumar H and Davim JP. (2011). Role of powder in the machining of $\mathrm{Al}-10 \%$ SiCp metal matrix composites by powder mixed electric discharge machining. Journal of composite materials 45: 133-151.

[7] Kapoor J, Singh S and Khamba JS. (2012) Highperformance wire electrodes for wire electrical discharge machining. Proceedings of the J. Wang, Fundamentals of erbium-doped fibre amplifiers arrays. IEEE J. Quantum Electron., submitted for publication Institution of Mechanical Engineers, Part B: Journal of Engineering Manufacture: 0954405412460354.

[8] Koshy P, Jain V and Lal G. (1996) Mechanism of material removal in electrical discharge diamond grinding. International Journal of Machine Tools and Manufacture 36: 1173-1185.

[9] C. J. Kaufman. (1995). Rocky Mountain Research Lab., Boulder, $\mathrm{CO}$, private communication.

[10] Koshy P, Jain V and Lal G. (1997). Grinding of cemented carbide with electrical spark assistance. Journal of Materials Processing Technology 72: 61-68.

[11] Krar S and Check A. (1997). Electrical discharge machining. The technology of Machine Tools, Glencoe/McGraw-Hill, New York.

[12] Komaraiah, M., Manan, M., Narasimha Reddy, P. \& Victor, S. (1988). Investigation of surface roughness and accuracy in ultrasonic machining. Precision engineering 10: 59-65.

[13] Kozak J. (2002). Abrasive electro discharge grinding (AEDG) of advanced materials, Archives of civil and mechanical engineering 2: 83-101.

[14] Lee H-T and Tai T-Y. (2003). Relationship between EDM parameters and surface crack formation, Journal of Materials Processing Technology 142: 676-683.

[15] Lauwers B, Kruth J-P, Liu W, Eeraerts W, Schacht B and Bleys P. (2004). Investigation of material removal mechanisms in EDM of composite ceramic materials, Journal of Materials Processing Technology 149: 347352.

[16] Kurnia W, Tan P, Yeo SH and Tan QP. (2009). Surface roughness model for micro-electrical discharge machining, Proceedings of the Institution of Mechanical
Engineers, Part B: Journal of Engineering Manufacture 223: 279-287. 